\title{
Life in leaf litter: Fungal community succession during decomposition
}

\section{Tennakoon DS ${ }^{1,2}$, Gentekaki $E^{1,2}$, Jeewon $\mathrm{R}^{3}$, Kuo $\mathrm{CH}^{4}$, Promputtha $\mathrm{I}^{5,6}$ and Hyde KD ${ }^{1,2,5,6,7}$}

${ }^{1}$ Center of Excellence in Fungal Research, Mae Fah Luang University, Chiang Rai, 57100, Thailand

${ }^{2}$ School of Science, Mae Fah Luang University, Chiang Rai, 57100, Thailand

${ }^{3}$ Department of Health Sciences, Faculty of Science, University of Mauritius, Reduit, Mauritius

${ }^{4}$ Department of Plant Medicine, National Chiayi University, 300 Syuefu Road, Chiayi City 60004, Taiwan

${ }^{5}$ Department of Biology, Faculty of Science, Chiang Mai University, Chiang Mai 50200, Thailand

${ }^{6}$ Environmental Science Research Center, Faculty of Science, Chiang Mai University, Chiang Mai, 50200, Thailand

${ }^{7}$ Innovative Institute of Plant Health, Zhongkai University of Agriculture and Engineering, Haizhu District, Guangzhou 510225, China

Tennakoon DS, Gentekaki E, Jeewon R, Kuo CH, Promputtha I, Hyde KD 2021 - Life in leaf litter: Fungal community succession during decomposition. Mycosphere 12(1), 406-429, Doi 10.5943/mycosphere/12/1/5

\begin{abstract}
Leaf litter decomposition plays a vital role in the nutrient budget of forest ecosystems. Fungal communities colonising leaf litter are "key players" in decomposition and nutrient recycling, because of their ability to produce a wide range of extracellular enzymes that facilitate breakdown of leaf litter. Fungal colonization of decomposing leaf litter is a sequential process during which fungal communities tend to change both quantitatively and qualitatively. Most previous studies on fungal succession have taken synecological approaches, recording fungal species assemblages at different stages of decomposition in various plant species. This paper brings together various studies on leaf litter decomposition, fungal succession of leaf litter including study methods, succession stages, controlling factors, limitations and future perspectives. We discuss high throughput methods as emerging complementary approaches to better understand species diversity and community dynamics. We propose the importance of current approaches combining morphological and molecular data in fungal succession studies. Nevertheless, there are still opportunities for further breakthroughs in this area as few research groups have applied these techniques to fungal succession experiments.
\end{abstract}

Key words - Colonization - fungal diversity - next generation sequencing - nutrient cycling substrate

\section{Introduction}

\section{Plant litter}

Plant litter accounts for a large part of the above ground net primary production of terrestrial ecosystems (Swift et al. 1979, Austin \& Vivanco 2006, Chakravarty et al. 2020). Simply, plant litter can be described as a collection of fallen leaves, twigs, seeds, flowers and other woody debris that accumulate naturally on the ground of forest environments, all of which subsequently enter the decomposition pathway in terrestrial ecosystems (Johnson \& Catley 2002, Berg \& McClaugherty 2008). Plant litter accumulation alters the surrounding environment by intercepting light, affecting 
animal activities, retaining moisture and maintaining soil temperature via evapotranspiration (Facelli \& Pickett 1991, Xiong \& Nilsson 1997, Graça 2001, Hättenschwiler et al. 2005, Sayer 2006, Pei et al. 2017). In particular, plant litter maintains forest productivity through important pathways involving nutrient cycling (Bray \& Gorham 1964, Lowman 1988, Rahman et al. 2013, Jia et al. 2016, Zhou et al. 2016, Giweta 2020). A generalized model of nutrient cycling process in forest ecosystem is presented in Fig. 1. During plant litter decomposition via physical, biological and chemical processes, nutrients are recycled and $\mathrm{CO}_{2}$ is released to the atmosphere (Krishna \& Mohan 2017, Veen et al. 2019a). Leaf litter accounts for over $70 \%$ of the total above ground litter fall in forests, while the other $30 \%$ is composed of twigs, seeds, flowers and other woody debris (Robertson \& Paul 1999).

\section{Leaf litter}

Fallen leaves, which accumulate on the ground as a natural layer, can be considered as leaf litter (Johnson \& Catley 2002). Leaf litter provides many benefits to the ecosystem, as it is the largest source of organic material and nutrients for the humus layer (Berg \& McClaugherty 2008, Purahong et al. 2016, Bani et al. 2018). Moreover, leaf litter acts as a protective layer against microhabitat fluctuations, soil erosion and compaction, while it also creates a microclimate that is favorable for fungal growth and fruit body production (Eaton et al. 2004, Koide et al. 2005, Sayer 2006, Shirouzu et al. 2009, Promputtha et al. 2017). Leaf litter provides nutrition and shelter for a variety of organisms. Consequently, the abundance and diversity of life forms inhabiting leaf litter is astounding, ranging from bacteria to fungi to macro-invertebrates (e.g. worms, mites, spiders, springtails, insect larvae and other invertebrates) (Graça 2001, Johnson \& Catley 2002, Koide et al. 2005, Shirouzu et al. 2009). Furthermore, leaf litter provides nesting materials for birds and other small animals (Olson 1994, Graça 2001, Vasconcelos \& Laurance 2005). The leaf litter layer not only enables rainwater to filter into the ground, but it also protects and nourishes the soil via decomposition (Burghouts et al. 1992, Chauvet et al. 1993, Graça 2001, Johnson \& Catley 2002, Sayer 2006, Donald et al. 2018).

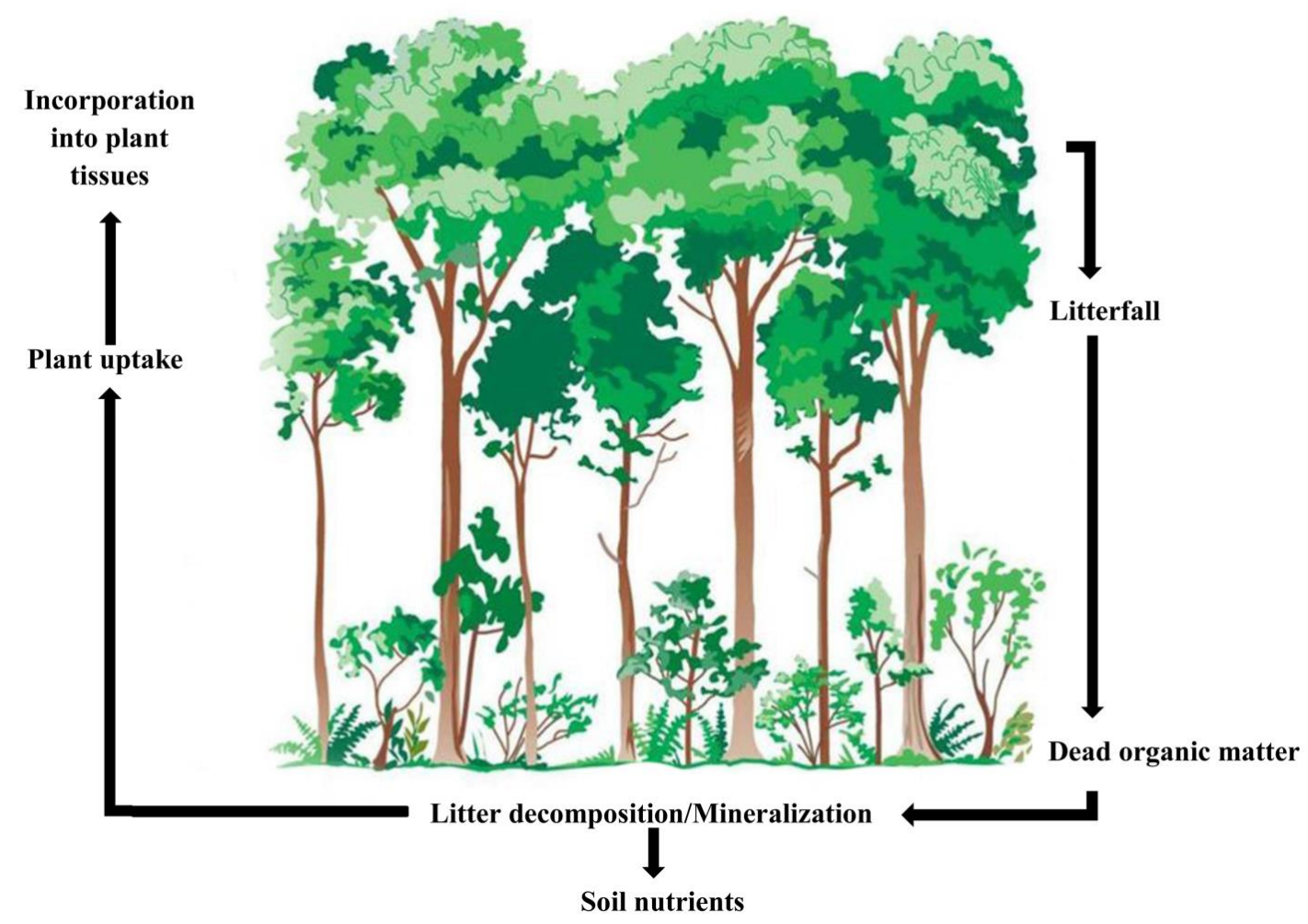

Figure 1 - Generalized model of nutrient cycling process in forest ecosystem (adapted from Rahman et al. 2013). 


\section{Leaf litter decomposition}

Leaf litter decomposition can be defined as "a biological process carried out by insects, worms, bacteria and fungi both on the soil surface and in the soil and encompasses a complex set of processes, including chemical, physical and biological agents" (Graça 2001, Hasanuzzaman \& Hossain 2014). In forest ecosystems, leaf litter decomposition comprises a major part of the nutrient cycling process, which is largely dependent on plant biodiversity (Melillo et al. 1982, Berg \& Laskowski 2006, Li et al. 2017, Osono 2017, Sayer et al. 2020). As the organic matter of leaf litter decomposes, a large proportion of carbon becomes lost via respiration of decomposer organisms, while nutrients are released in usable forms via mineralization (Swift et al. 1979, Krishna \& Mohan 2017, Veen et al. 2019a). The main phases of leaf litter decomposition are presented in Fig. 2. Leaf litter decomposition comprises two main simultaneous processes: (a) the microorganism-mediated mineralization and humification of lignin, cellulose and other compounds; (b) the leaching of soluble compounds into the soil whose carbon, nitrogen and other elements are gradually mineralized (Dechaine et al. 2005, Sayer et al. 2020). The nutrients that are released through the litter decomposition process into the soil are recycled as food sources by trees and other plants growing on the soil surface. In particular, these nutrients comprise micro- and macroelements that plants and animals require for growth (Sayer et al. 2020). Thus, litter decomposition is an important natural process in forest ecosystems, as it recycles vital components back to the environment (Leppert et al. 2017, Froufe et al. 2020, Sayer et al. 2020).

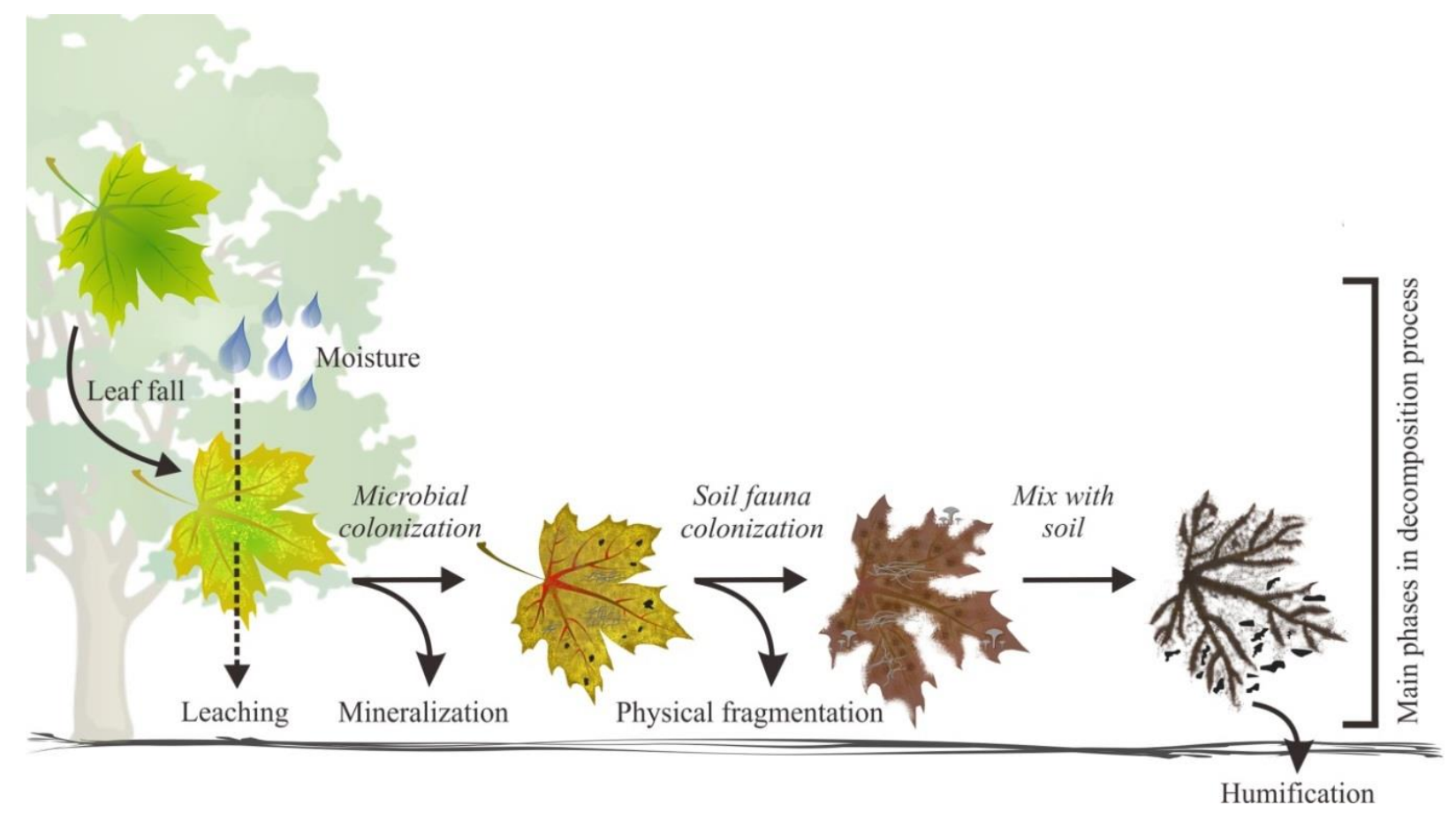

Figure 2 - The major phases of leaf litter decomposition.

There are many factors that influence the leaf litter decomposition process. Hou et al. (2005) described three types of interacting factors: (a) physico-chemical environment; (b) litter quality; (c) decomposer communities (Fig. 3). Climatic characteristics, such as temperature, precipitation, seasonal variations, and soil conditions relate to the physico-chemical environment (Hou et al. 2005, Bothwell et al. 2014, Ge et al. 2017). These strongly affect the rate of decomposition by modifying conditions for decomposers to act and by transforming litter organic matter into forms readily usable by plants (Swift et al. 1979, Berg et al. 1993, Gonzalez \& Seastedt 2001, Trofymow et al. 2002, Hou et al. 2005, Bothwell et al. 2014, Ge et al. 2017, Osono 2017). Purahong et al. (2014) and Yin et al. (2019) illustrated that forest system management practices can significantly influence environmental factors demonstrating an anthropogenic effect on leaf litter decomposition rates and nutrient dynamics. 
Leaf litter quality refers to the suitability of the substrate as a carbon, energy or nutrient source to the organisms that degrade it. The physical nature and biochemical composition of leaves determines litter quality (Berg 2014, Purahong et al. 2016). Physical features, such as leaf toughness, particle size, and leaf surface properties have an ability to affect accessibility of litter to decomposers, and thus can alter rates of colonization and patterns of decomposition and mineralization (Promputtha et al. 2002, Duong et al. 2008, Kearns \& Bärlocher 2008, Berg 2014). In particular, physical properties influence exchange of nutrients, water and oxygen between the substrate and the soil (Promputtha et al. 2002). Biochemical properties or leaf litter chemical components, such as initial $\mathrm{C}$ or $\mathrm{N}$ content, $\mathrm{C} / \mathrm{N}$ ratio, soluble sugars, polyphenols, waxes, cellulose, hemicellulose, pectin and lignin content concentrations are good indicators for leaf litter quality and residue decomposition rates. These chemical compounds have an effect not only on leaf litter decomposition rate, but also on the dynamics of nutrient mineralization and immobilization, which in turn define microbial communities of decomposers (Tian et al. 1997, Cotrufo et al. 1998, Perez-Harguindeguy et al. 2000, Hou et al. 2005, Purahong et al. 2014, Osono 2017, Bärlocher et al. 2020).

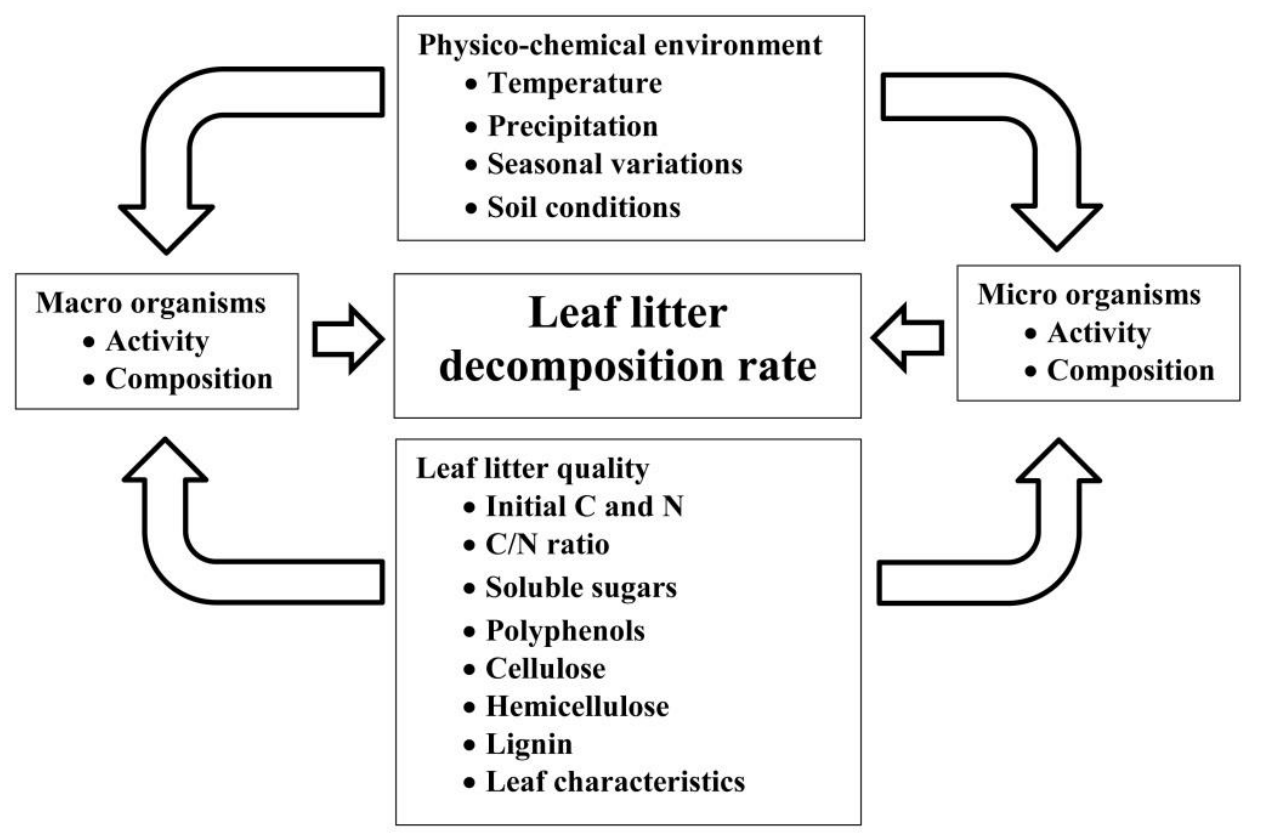

Figure 3 - The main factors that control leaf litter decomposition rate (adapted from Prescott et al. 2000).

The effect of different chemical components on variation of leaf litter decomposition has been discussed in detail in previous studies (Perez-Harguindeguy et al. 2000, Hou et al. 2005, Purahong et al. 2014, Osono 2017, Bärlocher et al. 2020, Pavlović et al. 2020). For instance, leaf litter with a low $\mathrm{C} / \mathrm{N}$ ratio and lignin content has been found to have higher decomposition rates in a great number of studies (Vargas et al. 2006, Wang et al. 2009, Yang \& Chen 2009, Purahong et al. 2016). In general, the concentrations of $\mathrm{C}$ and $\mathrm{N}$ in leaf litter vary with the plant species (Guendehou et al. 2014). Polyphenols are compounds of highly variable solubility and are relatively resistant to decay (Kainulainen \& Holopainen 2002, Ristok et al. 2017). The role of polyphenols in leaf litter decomposition is inhibitory due to their function in precipitating enzymes (Ristok et al. 2017). Thus, the amount and type of polyphenols plays a role in rate of decomposition. Similarly, polymers of the plant cell wall have variable effects on decomposition. Cellulose is the main structural polymer of plant cell walls comprising microfibrils, which are resistant to attack by microbial communities. Hemicellulose is a microfibril-free polymer that forms hydrogen bonds with cellulose and lignin. Collectively, these are referred to as "cross linking glucans" (Fioretto et al. 2005, Krishna \& Mohan 2017). In contrast, lignin is an extremely flexible 
molecule that coats cell walls and combines chemically with cellulose to form lignocellulose (Pavlović et al. 2020). Amount of cellulose, hemicellulose and lignin are useful indicators of the rate of leaf litter decay. High contents of cellulose, hemicellulose and lignin have a rate-reducing influence on leaf litter decomposition and have been discussed in detail elsewhere (Talbot \& Treseder 2012, Moorhead et al. 2014, Zhu et al. 2016, Krishna \& Mohan 2017, Pavlović et al. 2020).

Decomposer communities include both micro and macro organisms, such as bacteria, fungi, protozoa, nematodes, mites, collembolans, annelids (i.e. enchytraeids, earthworms) and micro- and macro-arthropods (i.e. spiders, myriapoda, woodlice and insects). Among the microfauna in leaf litter, fungi are the leading decomposers having greater than $75 \%$ potential of reducing organic matter than other microorganisms (Osono 2007, Holden et al. 2013).

\section{The role of fungi in leaf litter decomposition}

Fungi are considered as the "key players" in leaf litter decomposition, because of their ability to produce a wide range of extracellular enzymes (Dilly \& Munch 2001, Dilly et al. 2004, Osono 2017, Zhang et al. 2018). These enzymes help to break down the litter lignocellulose layers that other organisms are unable to decompose (Kjoller \& Struwe 1982, Cooke \& Rayner 1984, Berg \& McClaugherty 2003, Bucher et al. 2004, Osono 2017, Zhang et al. 2018). In particular, the most significant enzymes involve those that break down substances of the plant cell wall, such as cellulases, hemicellulases, pectinases, phenol oxidases and polygalacturonases. The collective action of these enzymes weakens the plant cell wall, thus uncovering hemicellulose and cellulose for further enzymatic degradation (Romaní et al. 2006, Osono 2007, Zhang et al. 2018). Some enzymes, such as peptidases, ureases, and phosphatases are important for microbial acquisition of nitrogen and phosphorus (Sinsabaugh et al. 2002, Romaní et al. 2006, Zhang et al. 2018), while others such as phenol oxidases, peroxidases and laccases help catalyze degradation of lignin (Romaní et al. 2006). Several of these enzymes are widely used in agriculture, bioremediation, food industry, medicine, and pharmaceutical industry (Gupta et al. 2016, Hyde et al. 2019, Fayyad et al. 2020). Some common fungi involved in leaf litter decomposition are listed in Table 1.

Table 1 Fungi capable of utilizing different components of leaf litter (Berg 2000, Lynd et al. 2002, Berg \& McClaugherty 2003, Krishna \& Mohan 2017)

\begin{tabular}{|l|l|}
\hline \multicolumn{1}{|c|}{ Components } & \multicolumn{1}{c|}{ Fungal species } \\
\hline Cellulose & $\begin{array}{l}\text { Alternaria, Aspergillus, Chaetomium, Coprinus, Fomes, Fusarium, Myrothecium, } \\
\text { Penicillium, Polyangium, Polyporus, Rhizoctonia, Rhizopus, Trametes, Trichoderma, } \\
\text { Trichothecium, Verticillium, Zygorynchus }\end{array}$ \\
\hline Hemicellulose & $\begin{array}{l}\text { Alternaria, Aspergillus, Chaetomium, Coriolus, Fomes, Fusarium, Helminthosporium, } \\
\text { Penicillium, Polyporus, Rhizopus, Trichothecium, Zygorynchus }\end{array}$ \\
\hline Lignin & $\begin{array}{l}\text { Arthrobotrys, Cephalosporium, Clavaria, Collybia, Flammula, Humicola, Hypholoma, } \\
\text { Lepiota, Mycena, Pholiota }\end{array}$ \\
\hline Starch & Aspergillus, Fomes, Fusarium, Polyporus, Rhizopus \\
\hline Pectin & Fusarium, Verticillium \\
\hline Inulin & Aspergillus, Fusarium, Penicillium \\
\hline Chitin & $\begin{array}{l}\text { Absidia, Aspergillus, Fusarium, Gliocladium, Mortierella, Mucor, Penicillium, } \\
\text { Thamnidium, Trichoderma }\end{array}$ \\
\hline Cutin & Mortierella, Penicillium, Rhodotorula \\
\hline Tannin & Aspergillus, Penicillium \\
\hline Humic acid & Penicillium \\
\hline Fulvic acid & Poria \\
\hline
\end{tabular}

Notably, some fungal species that have been associated with living leaves have also been found in association with leaf litter (Hyde et al. 2007, Promputtha et al. 2007, 2010). This observation has led to the hypothesis that certain fungal species may change from an endophytic to 
a saprotrophic strategy (Promputtha et al. 2007, 2010). Phylogenetic analysis has further confirmed that fungi cultured from living leaves and decaying litter may indeed belong to the same taxa (Promputtha et al. 2007, 2010, De Silva et al. 2019). For instance, Lasiodiplodia pseudotheobromae has been found both as endophyte and saprobe in Magnolia candolii (Magnoliaceae) (De Silva et al. 2019). Promputtha et al. (2007) found that isolates of Colletotrichum, Fusarium, Guignardia, and Phomopsis, all of which are common plant endophytes, have high sequence similarity and close phylogenetic affinity to their saprotrophic counterparts in Magnolia liliifera. Promputtha et al. (2010) also revealed several endophytes, namely Colletotrichum gloeosporioides, Colletotrichum sp., Corynespora cassiicola, Fusarium sp., Guignardia mangiferae, Leptosphaeria sp. and Phomopsis sp., which were morphologically and phylogenetically similar to saprobes. Promputtha et al. (2010) findings further illustrated that some endophytes are capable of producing degrading enzymes once leaves undergo senescence in order to survive as saprobes (i.e. xylanase and mannanase). Endophytes with the ability to produce degrading enzymes might have a significant role as litter decomposers, but they do not harm host tissues in the living host. These degrading enzymes are under genetic control and are later produced as survival responses to enable fungi to colonize leaf litter and adapt a saprophytic lifestyle ecological strategy (Promputtha et al. 2010).

The ability of fungal communities to decompose leaf litter has been frequently investigated under field and laboratory conditions (Promputtha et al. 2002, 2017, Tang et al. 2005, Paulus et al. 2006, Duong et al. 2008, Vořŕšková \& Baldrian 2013). Many studies have combined litterbag techniques with cultivation-based methods followed by the isolation and identification of fungal decomposers (Promputtha et al. 2002, 2017, Paulus et al. 2003, Koide et al. 2005, Osono 2005, Sridhar et al. 2010). Consequently, researchers have found that the overall leaf litter decomposition is a sequential process that initially involves the loss of the less recalcitrant components (i.e. oligosaccharides, organic acids, hemicellulose and cellulose) followed by the degradation of the remaining highly recalcitrant compounds (i.e. lignin, suberin). Furthermore, studies have revealed that fungal communities tend to change both quantitatively and qualitatively during the decomposition period (Fryar 2002, Promputtha et al. 2002, 2017, Tang et al. 2005, Paulus et al. 2006, Voř́šková \& Baldrian 2013). The time-related change of fungal species during decomposition is called "Fungal succession".

\section{Fungal succession in leaf litter}

The most broadly accepted definition of fungal succession is that of Rayner \& Todd (1979), who defined it as "the sequential occupation of the same site by thalli (normally mycelia) either of different fungi or different associations of fungi". Similarly, Dix \& Webster (1995) defined succession as "a time-related change in fungal community structure". Frankland (1998) described fungal succession as "diversity of fungal species changes over space and time, each species being adapted for occupation of particular niches". Fryar (2002) has suggested that "mycelial succession" might be a better term than fungal succession, as it highlights the importance of changes in mycelial distribution.

There have been many studies on fungal succession of different types of leaf litter (Koide et al. 2005, Tang et al. 2005, Paulus et al. 2006, Duong et al. 2008, Shirouzu et al. 2009, Promputtha et al. 2017), woody litter (Kodsueb et al. 2008, Dossa et al. 2021), logs (Jankowiak 2005) and in aquatic environments (Hyde et al. 1998, Raviraja et al. 1996, 1998a, Prasannarai et al. 1999, Sridhar \& Bärlocher 2000, Tsui et al. 2000, Ho et al. 2002, Krauss et al. 2003, Maria \& Sridhar 2003, Maria et al. 2006, Ananda et al. 2008, Sridhar et al. 2010) in both tropical and temperate regions. Most have focused on fungi of individual host species, including Manglietia garrettii (Promputtha et al. 2002), Neolitsea dealbata (Paulus et al. 2003), Camellia japonica (Koide et al. 2005), Ficus pleurocarpa (Paulus et al. 2006), Castanopsis diversifolia (Duong et al. 2008), Magnolia liliifera (Kodsueb et al. 2008), Shorea obtusa (Osono et al. 2009), Hevea brasiliensis (Seephueak et al. 2010), Anacardium occidentale and Pavetta indica (Shanthi \& Vittal 2010a, b). Those studies have provided a host-fungus database that can be used for future investigations, have 
increased knowledge of fungal diversity, and have contributed to new fungal discoveries. In the majority of these studies, development of fungal communities was observed after leaf litter samples were incubated in moist chambers (Promputtha et al. 2002, 2017, Tang et al. 2005, Paulus et al. 2006, Duong et al. 2008, Voř́šková \& Baldrian 2013).

\section{Factors influencing leaf litter fungal succession}

The effect of different factors on variation of leaf litter fungal communities has been discussed in detail (Dix \& Webster 1995, Photita et al. 2001, Promputtha et al. 2002, Duong et al. 2008, Purahong et al. 2016). Both biotic and abiotic factors influence fungal communities of leaf litter during decomposition (Purahong et al. 2016, Promputtha et al. 2017, Vivelo \& Bhatnagar 2019). Specifically, knowing which factors drive leaf litter fungal communities is essential for understanding how ecosystems function and how vulnerable they are to environmental changes (Glassman et al. 2018, Yin et al. 2019). Heterogeneity of tree species, fungal colonization priority effects, interspecific competition between fungal species and inter-kingdom relationships between bacteria and fungi, are some of the biotic factors that affect fungal colonization in leaf litter (Lodge \& Cantrell 1995, Paulus et al. 2003, Duong et al. 2008, Promputtha et al. 2017).

Many recent studies have focused on revealing the influence of tree species on composition of fungal communities and forest ecosystem functions (Purahong et al. 2016, Saitta et al. 2018, Wu et al. 2018, Zhang et al. 2018). In particular, physical and chemical characteristics of leaves vary tremendously among tree species, thus have noteworthy effect on fungal community composition through releasing limiting resources, supplying a wide range of substrates and making variable microclimate (Purahong et al. 2016, Huang et al. 2017). The tree canopy also has large influence on fungal composition through its effect on hydrological and temperature conditions leading to microclimatic conditions favorable for fungal communities (Prescott 2002, Hättenschwiler 2005, Sridhar 2009, Chauvet et al. 2016).

Priority effect is a significant biotic factor referring to colonization of fungal species in leaf litter (Boddy \& Hiscox 2017). In particular, early colonizers may have adaptations for colonizing a substrate, whereas fungal species appearing later in the succession might be more adapted for invasion of existing communities by interspecific competition (Lin et al. 2015, Veen et al. 2019a, Vivelo \& Bhatnagar 2019). Some fungal communities contribute to excretion of antibiotic toxins and those directly affect growth and development of other fungal species (Shearer 1995). For example, metabolites such as glycol, chlorohydrins and bromohydrin can affect the development of fungal communities (Paulus et al. 2003, Duong et al. 2008). In addition, bacterial and fungal interactions also significantly influence fungal colonization in leaf litter (Johnston et al. 2016, Purahong et al. 2016). Generally, bacterial and fungal communities might have competitive or cooperative interactions with each other for the same plant substrates (Romaní et al. 2006, Purahong et al. 2016, Zhao et al. 2020). An example of cooperative interaction is when N-fixing bacteria increase $\mathrm{N}$ availability in leaf litter, thus supporting fungi to meet their nutrient requirements (Purahong et al. 2016, Zhao et al. 2020). The interaction has been further confirmed in high throughput sequence based studies, whereby some lignocellulose fungal decomposers (i.e. Clitocybe spp., Mycena spp.) co-occurred with nitrogen fixing bacterial OTUs (i.e. Bradyrhizobium, Mesorhizobium, Pseudomonas and Rhizobium) (Purahong et al. 2016, Zhao et al. 2020).

Abiotic factors, such as leaf litter quality, temperature, precipitation, seasonal variations, soil characteristics and plot related factors (i.e. elevation, slope), also influence colonization of fungal communities on leaf litter (Raviraja et al. 1998b, Promputtha et al. 2002, Bothwell et al. 2014, Ge et al. 2017, Osono 2017, Ritter et al. 2020). The effect of different abiotic factors on variation of fungal colonization of leaf litter has been discussed in detail in previous studies (Dix \& Webster 1995, Niks \& Rubiales 2002, Purahong et al. 2014, 2016, Osono 2017). Several authors (Devis \& Yadava 2007, Tripathi et al. 2009) have revealed that leaf litter decomposition was slow in winter and fast during the rainy season and concluded that the major reasons could be the presence of sufficient rainfall, suitable moisture, and consequently, higher fungal populations. 
Leaf litter quality is mainly based on physical nature and biochemical composition of the leaves (Raviraja et al. 1998b, Parungao et al. 2002, Promputtha et al. 2002, Hou et al. 2005, Purahong et al. 2016, Osono 2017). Physical characteristics, such as leaf toughness, particle size, and leaf surface properties affect the accessibility of litter to fungal communities, and thus alter rates of colonization and patterns of decomposition (Promputtha et al. 2002, Duong et al. 2008, Berg 2014). For example, Photita et al. (2001) showed that large leaves of Musa acuminata support higher fungal diversity than the smaller leaves of other plants. Promputtha et al. (2002) examined the same concept and suggested that large leaves provide a greater surface area, which can be used as substrata for fungal growth and as a consequence, diverse fungal communities can be found on their leaf litter. In addition, Promputtha et al. (2017) suggested that slowly decaying leaves might provide substrata over a longer period of time, thus allowing development of more fungal species. Some leaves have surface hairs that might catch fungal spores and thus prevent colonization on leaf litter (Dix \& Webster 1995, Niks \& Rubiales 2002, Kearns \& Bärlocher 2008). Fungal spores that become entrapped by hydrophobic hairs and germinate, might die before reaching the leaf surface if water films dry out. Sometimes, the hairs increase the chances of spore deposition by increasing the boundary layer thickness (Andrews \& Hirano 2012). Leaves with wax layers are hydrophobic and thus, spores are particularly susceptible to run-off when these leaves become wet (Paulus et al. 2003, Andrews \& Hirano 2012). Presence of biologically active substances (both specific and nonspecific) in some plant tissues might inhibit fungal growth. Hence, fungal colonization of these leaves depends on the ability of the fungus to overcome the inhibitory effect of these substances by producing enzymes necessary to degrade them. Phenolics, such as catechol, benzoic acid, phydroxybenzoic acid and p-hydroxybenzaldehyde affect litter-inhabiting fungi as these compounds can inactivate their respiratory and extracellular enzymes (Dix \& Webster 1995).

\section{Fungal succession stages during leaf litter decomposition}

Most previous leaf litter fungal succession studies have shown that fungal colonization patterns tend to change both quantitatively and qualitatively during the decomposition period (Promputtha et al. 2002, 2017, Tang et al. 2005, Paulus et al. 2006, Sridhar 2012, Voř́ŕšková \& Baldrian 2013). These studies have also illustrated that the replacement of fungal species over time occurs in several succession stages (Promputtha et al. 2002, 2017, Tang et al. 2005, Paulus et al. 2006). Many researchers have recognized similar patterns of fungal occurrence with the passage of time, viz. early, intermediate or late colonizers (or alternative names) (Garrett 1963, Hudson 1968, Tsui et al. 2000, Promputtha et al. 2002, 2017, Tang et al. 2005, Paulus et al. 2006, Jeewon et al. 2018). Based on the nutritional hypothesis, which refers to the sequence of fruit bodies, Garrett (1963) proposed the following four stages in the succession of any substrate including leaf litter (Table 2). Fungal colonization begins with "weak parasites" invading senescent tissues (stage 1a). Secondly, "primary sugar fungi" appear which utilize simple carbon compounds after the litter is deposited on soil (stage 1). Sugar fungi, are mostly non-cellulolytic, fast-growing species that depend on readily available sugars, such as hexoses, pentoses and other carbon sources simpler than cellulose, such as pectins and starch. In stage 2, "cellulose decomposers associated secondary saprophytic sugar fungi" act on dead leaves. These comprise mostly asexual forms of ascomycetes. Finally in stage 3, basidiomycetes act on substrates as the "lignin decomposers" (stage 3). Subsequently, Hudson (1968) referred to Garrett (1963) and described the substratum succession process using a variety of leaf litter types. In particular, "phylloplane fungi" were mentioned as common primary saprobes in the early stages of decomposition. The nutritional hypothesis has been broadly discussed by Fryar (2002), who suggested that fungal succession should refer to the replacement of fungal mycelium and the sequence of fungal sporulation rather than the term "fruit body succession".

Frankland (1976) investigated the decomposition of bracken leaf petioles over a five-year period and revealed the pattern of fungal succession. According to Frankland (1976) findings, decomposition started with weak parasites, followed by appearance of primary saprobes, then secondary saprobes and finally ended with common soil fungal species. Frankland (1992) 
illustrated this process in a similar way by using a 3-stage approach, which defined fungal communities as arrival, establishment and replacement. Dix \& Webster (1995) introduced a broad set of succession communities as the "Pioneer", "Mature" and "Impoverished communities" (Table 3). Many recent studies have used Dix and Webster's terminology (Ho \& Hyde 2002, Promputtha et al. 2002, 2017, Kodsueb et al. 2008, Thongkantha et al. 2008). Dix \& Webster (1995) suggested that both species diversity and number of "individuals" are low during the earliest stages of fungal colonization and then go through a period of stability with high diversity and a final decline of total fungal community numbers.

Table 2 The initial concept of fungal succession on a leaf litter (or any substrate) (modified from Garrett 1963)

\begin{tabular}{|l|l|l|l|}
\hline \multicolumn{1}{|c|}{ Senescent leaf } & \multicolumn{3}{c|}{ Dead leaf } \\
\hline Stage 1a & Stage 1 & Stage 2 & Stage 3 \\
\hline Weak parasites & "Primary saprobic sugar & "Cellulose decomposers & "Cellulose and lignin \\
(Pioneer colonizers) & fungi" & and associated & decomposers" \\
- Utilize readily & - Living on sugars & secondary saprophytic & - Utilize cellulose and \\
available sugars, & (hexoses \& pentoses) & sugar fungi" & lignin \\
pentoses & and carbon compounds & - Utilize cellulose & - basidiomycetes \\
& $\begin{array}{l}\text { simpler than cellulose } \\
\text { (pectin \& starch) }\end{array}$ & - Commonly & \\
& ascomycetes & \\
\hline
\end{tabular}

Table 3 Description of Dix and Webster (1995) fungal succession stages (Promputtha et al. 2002)

\begin{tabular}{|l|l|}
\hline Succession stage & Fungal communities changes \\
\hline Pioneer community & $\begin{array}{l}\text { This community consists of pioneer species that have a low percentage } \\
\text { occurrence (Dix \& Webster 1995). Pioneer species tend to be fast } \\
\text { growing, short lived, and capable of rapid and wide dispersal } \\
\text { (Luczkovich \& Knowles 2000). This community type has low species } \\
\text { diversity and few species have high percentage occurrence (Dix \& } \\
\text { Webster 1995). }\end{array}$ \\
\hline Mature community & $\begin{array}{l}\text { The species diversity in mature communities is high and has peaked. } \\
\text { There are a number of species with low percentage occurrence. } \\
\text { However, several species have a high level of occurrence. The } \\
\text { dominant species have extremely high levels of occurrence. During the } \\
\text { later stages of the mature community, the number of dominant species } \\
\text { declines, but species diversity is still high (Dix \& Webster 1995). }\end{array}$ \\
\hline $\begin{array}{l}\text { Impoverished } \\
\text { community }\end{array}$ & $\begin{array}{l}\text { The species diversity and the number of species in an impoverished } \\
\text { community, decline. The community is dominated by a few species } \\
\text { with high levels of occurrence (Dix \& Webster 1995). These dominant } \\
\text { species tend to be persistent and longer-lived species (Luczkovich \& } \\
\text { Knowles 2000). However, there are still some species with low levels } \\
\text { of occurrence (Dix \& Webster 1995). }\end{array}$ \\
\hline
\end{tabular}

\section{Direct and indirect methods of fungal isolation in succession studies}

To observe fungal succession in leaf litter, we should be able to observe the fruit bodies or mycelia occupying a specific area in leaf litter (Fryar 2002). However, fungal species identification is challenging, because many species are non-culturable or consist of dormant or senescent spores (Jeewon \& Hyde 2007, Jeewon et al. 2017). Paulus et al. (2003, 2006) described different methods to detect or isolate fungi from leaf litter, and subdivided them into direct and indirect approaches based on Booth (1971). Direct methods usually involve observing fruit bodies on leaf litter in the 
field or laboratory over a time period and numerous researchers have used these methods for their succession studies (Promputtha et al. 2002, 2017, Zhou \& Hyde 2002, Paulus et al. 2003, 2006, Tang et al. 2005, Duong et al. 2008, Kodsueb et al. 2008, Shanthi \& Vittal 2012, Senanayake et al. 2020). However, direct methods might underestimate fungal diversity in leaf litter, since fruit bodies may not be present at the time of examination (Paulus et al. 2003, 2006). In addition, most previous studies have not considered non-sporulating mycelia within the leaves and therefore, it is difficult to conclude that the observed fungal species are the only species active in fungal succession (Jones 1963, Tsui et al. 2000, Jones \& Hyde 2002). Another problem, in terms of statistical analysis of the data, is that some fungal species are present as single fruit bodies, while others sporulate over the entire surface of the leaf. Direct isolation methods have been known to be better for obtaining more sexual stages of fungi than indirect approaches (Paulus et al. 2003).

The most common indirect approaches are pulverization, washing, and planting of particle suspensions (Polishook et al. 1996, Paulus et al. 2003). Indirect approaches can potentially capture greater fungal species diversity. However, these methods exclude fungi that grow slowly or cannot grow at all on agar plates and can encourage the growth of fast growing ubiquitous species, such as Aspergillus, Fusarium, Penicillium and Trichoderma. Therefore, the results would probably not be representative of the true extent of fungal diversity (Promputtha et al. 2002). Indirect methods have been criticized in some studies, because they recover both active fungi and dormant spores that do not necessarily participate in leaf decay processes (Paulus et al. 2003). Both direct and indirect methods suffer from various difficulties and advanced techniques are essentially needed to overcome fungal identification challenges. Molecular approaches have become instrumental in investigating leaf litter fungal succession as they directly detect both fruiting structures and mycelia present in leaves.

\section{Molecular approaches to studying leaf litter fungal succession}

Mycologists have traditionally used morphology as a main means to identifying species and thus many earlier taxa were established using brief descriptions along with line drawings (Ellis 1971, Pirozynski \& Shoemaker 1971, Nagraj 1978, Sutton 1980). Nevertheless, proper identification of fungal species is challenging, since morphology-based identification suffers from phenotypic plasticity, which may lead to misinterpretations. Moreover, some species are difficult to observe with the unaided eye, while others are rarely cultivable on artificial media. Thus, characterizing complex microbial communities exhaustively poses a challenge (Prosser et al. 2007). Combining molecular and morphological data is very promising for species delimitation and identification, taxonomic classification and phylogenetic inference. Phylogenetic analysis has also been applied to aid in fungal species identification since the 1990s (White et al. 1990, Bruns et al. 1991, Nikolcheva et al. 2003). DNA sequence analyses are currently used on a routine basis in fungal taxonomy at all levels.

In previous fungal succession experiments, identification of fungal communities relied heavily on cultural characterization of isolates followed by morphological observations and identification (Hudson 1968, McKenzie \& Hudson 1976, Berg 1991, Bills \& Polishook 1994, Hasegawa \& Takeda 1996, Frankland 1998, Promputtha et al. 2002). However due to the intricacies of morphological characters, many members of fungal communities have never been properly identified to species level (McKenzie \& Hudson 1976, Berg 1991, Bills \& Polishook 1994, Promputtha et al. 2002). Moreover, fungal species that exist as mycelial (vegetative) propagules that never produce spores are left unaccountable, and therefore provide biased accounts of fungal diversity (Jones \& Hyde 2002, Promputtha et al. 2002, 2007). Recent fungal succession studies using DNA sequencing coupled with phylogenetic analysis have paved the way for reliable identification, as well as, classification of a number of unidentified mycelial propagules (Ottosson 2013, Voříšková \& Baldrian 2013, Peršoh 2015, Liu et al. 2019, Veen et al. 2019a). In particular, PCR amplification with fungal specific primers and creation of clonal libraries followed by traditional Sanger sequencing is one of the methods used to identify fungal species in a community. Nevertheless, when using this method, it is not always possible to pick enough clones to obtain a 
representative sampling of the community. Subsequently, with the improvement in technology and the economic accessibility of next generation sequencing (NGS) approaches, it is now possible to study fungal diversity in detail (Voř́ŕšková \& Baldrian 2013, Liu et al. 2017, Bonanomi et al. 2019, Vivelo \& Bhatnagar 2019). Many recent succession studies have used NGS approaches to identify fungal communities and have revealed large number of taxa that could not be recovered before (Schmidt et al. 2013, Voříšková \& Baldrian 2013, Liu et al. 2017, Bonanomi et al. 2019, Vivelo \& Bhatnagar 2019, Veen et al. 2019a). Next generation sequencing approaches have delivered insights into fungal ecology and improved understanding of the diversity and distribution patterns of fungal communities (Voříšková \& Baldrian 2013, Hongsanan et al. 2018, Veen et al. 2019b).

Basically, NGS is a high-throughput approach that generates thousands to millions of sequences (Takahashi et al. 2014) using a variety of platforms (e.g. Illumina, PacBio, nanopore etc). High-throughput DNA sequencing provides a comprehensive profile of the fungal community present as all or at least most members are amplified (Hongsanan et al. 2018). Nuclear ribosomal internal transcribed spacer (ITS) region has been used often to identify the widest possible range of fungal species (Dissanayake et al. 2018, Jayawardena et al. 2018, Purahong et al. 2018). These approaches are not biased towards easily culturable and fast growing fungal species and provide an alternative means for identifying unculturable fungal species (Boers et al. 2012, Shendure \& Ji 2008, Voř́ŕšková \& Baldrian 2013). For example, Shirouzu et al. (2009) examined the fungal succession process associated with the decay of oak leaves by using washing method and revealed 83 species of 57 genera that were present during the decomposition. Subsequently, Vorríšková \& Baldrian (2013) examined the development of the fungal community composition in oak leaves by using NGS and revealed 1874 operational taxonomic units (OTUs) belonging to 387 fungal genera.

Despite all the sequencing advantages of NGS, there are limitations. In particular, the sequences derived from NGS can be identified only down to the genus or higher taxonomic level, but not species level (Jayawardena et al. 2018, Dissanayake et al. 2018, Hongsanan et al. 2018, Tedersoo et al. 2020). One of the reasons is that NGS targets only a short region (such as ITS1 or ITS2) of high variability, thus reliable sequence alignments are difficult to obtain (Schoch et al. 2012, Jayawardena et al. 2018, Dissanayake et al. 2018, Purahong et al. 2018, Tedersoo et al. 2020). For example, Colletotrichum and Fusarium species have low resolution for the ITS2 region making their identification especially problematic (Laurence et al. 2014, Jayawardena et al. 2018, Dissanayake et al. 2018), and thus other gene regions are needed to resolve their phylogenetic affinities. Importantly, the short sequence length remains a major weakness of most NGS approaches (Ambardar et al. 2016, Tedersoo et al. 2018, 2020). Nevertheless, Pacific Biosciences (PacBio) and nanopore sequencing platforms have the potential to overcome the length limitation, but these have rarely been used in environmental studies (Tedersoo et al. 2018, Purahong et al. 2019). Moreover, the high error rate of these platforms is also a challenge that needs to be overcome (Tedersoo et al. 2018, Amarasinghe et al. 2020, Tedersoo et al. 2020). A summary of advantages and disadvantages of recent NGS technologies in leaf litter fungal succession studies are shown in Table 4.

\section{The importance of leaf litter fungal succession studies}

\section{Global fungal diversity and where are the undescribed fungal species?}

Fungi are diverse in morphology, exhibit different modes of reproduction and dispersal mechanisms (Promputtha et al. 2007, Hyde et al. 2018, 2020). They have different lifestyles, including being biotrophs, endophytes, hemi-biotrophs, necrotrophs and saprotrophs (De Silva et al. 2016, Hyde et al. 2018). The extent of global fungal diversity has always been debatable, due to mycologists estimating fungal species numbers using various criteria. For instance, Hawksworth (1991) estimated that the number of fungi is 1.5 million and subsequently other mycologists have proposed different estimates, viz. 1 million (Rossman 1994), 9.9 million (Cannon 1997), 0.5 million (May 2000), 0.5-9.9 (Hawksworth 2001), 3.5-5.1 million (O'Brien et al. 2005), 5.1 million (Blackwell 2011). Hawksworth \& Lücking (2017) revised the fungal diversity estimation upwards 
to 2.2-3.8 million species. However, all these estimates are much higher than the 100,000 species that are presently known and thus, many species are still undescribed (Hyde et al. 2020). Therefore, the emerging question is: where can the missing species be?

Possible reasons for the observed discrepancy can be due to fungi being poorly studied in many countries, regions, and hotspots (Hyde et al. 2018, 2020). In support of this, a recent study on the fungi of northern Thailand showed that up to $96 \%$ of species found in the country were new to science (Hyde et al. 2018). Another possible reason is that many substrates (i.e. leaf litter, flower petals, soil) are poorly studied. Therefore, future research needs to focus on identifying fungi from poorly studied substrates and regions. There is also a dire need to include novel DNA-based sequence approaches to recover uncultured taxa from environmental samples.

Table 4 Advantages and disadvantages of recent Next-Generation Sequencing Technologies in leaf litter fungal succession studies (Garrido-Cardenas et al. 2017, Tedersoo et al. 2018)

\begin{tabular}{|l|l|l|}
\hline NGS platform & Advantages & Disadvantages \\
\hline \multirow{2}{*}{ Illumina } & Highest confirmed output & Short reading length \\
\cline { 2 - 3 } & lowest error rates, High accuracy & High cost per reading \\
\hline \multirow{2}{*}{ Ion Torrent Sequencing } & Low instrumental and operational cost & Short reading length \\
\cline { 2 - 3 } & Fast sequence runs & High error rate \\
\hline \multirow{2}{*}{ Pacific Biosciences (PacBio) } & Long reading length available & High error rate \\
\cline { 2 - 3 } & Fast sequence runs & High cost per reading \\
\hline \multirow{2}{*}{$\begin{array}{l}\text { Oxford Nanopore } \\
\text { Technologies }\end{array}$} & Fast sequence runs & High error rate \\
\cline { 2 - 3 } & Long reading length available & Biased errors \\
\cline { 2 - 3 } & Low instrumental and operational cost & High cost per reading \\
\hline
\end{tabular}

\section{The contribution of leaf litter fungal succession studies to the estimation of global fungal diversity}

Despite fungi having a critical role in decomposition of leaf litter, fungal diversity in the majority of host species is not well documented. Researchers have made considerable effort into establishing more reliable ways to uncover fungal diversity in leaf litter of various host species through succession studies. For instance, Promputtha et al. (2002) experimented on senescent leaves of Manglietia garrettii (Magnoliaceae) and found 22 species including Hyponectria manglietiae, Volutella sp., Gliocladium sp., Sporidesmium crassisporum and Cylindrocladium floridanum as the most common species. Paulus et al. $(2003,2006)$ examined fungal succession on Neolitsea dealbata (Lauraceae) and Ficus pleurocarpa (Moraceae) revealing 112 and 104 fungal taxa respectively. Shanthi \& Vittal (2010a, b) examined fungal succession on Anacardium occidentale (Anacardiaceae) and Pavetta indica (Rubiaceae) and revealed 142 and 54 taxa respectively during the decomposition period. Duong et al. (2008) worked on leaf litter of Castanopsis diversifolia and yielded 112 taxa. Fungal succession studies on leaf litter of different hosts i.e. Camellia japonica (Koide et al. 2005), Hevea brasiliensis (Seephueak et al. 2010), and Shorea obtusa (Osono et al. 2009) have also revealed high number of fungal species. These studies have shed some light on the diverse fungal communities inhabiting leaf litter in various host species and have provided a better resolution on global fungal diversity and a host-fungus database for future studies. A summary of previous leaf litter fungal succession studies is shown in Table 5.

\section{Current limitations and future perspectives of leaf litter fungal succession studies}

Surveying the actual fungal diversity on leaf litter during the decomposition period is challenging. While many leaf litter succession experiments have documented fungal diversity of various host species, only very few have determined the actual mechanism for succession (Frankland 1992). Most have observed the occurrence of fruiting bodies on leaf litter, but have not considered the mycelia in a given area of leaves over time. Consequently, this has underestimated the actual fungal diversity in successions studies. A few studies have, however, observed both fruiting structures and mycelia in succession and have revealed the succession patterns as well 
(Ponge 1991, Osono \& Takeda 2001). Experiments based on molecular approaches are very promising to widen our knowledge on diversity and identification of unidentified fruiting structures and mycelia in leaf litter during fungal succession studies.

Table 5 Summary of previous leaf litter succession studies during 2000-2020

\begin{tabular}{|l|l|l|l|}
\hline Host & Country & $\begin{array}{l}\text { Number of recorded } \\
\text { fungal species }\end{array}$ & Reference \\
\hline $\begin{array}{l}\text { Manglietia garrettii } \\
\text { (Magnoliaceae) }\end{array}$ & Thailand & 22 & Promputtha et al. (2002) \\
\hline $\begin{array}{l}\text { Neolitsea dealbata } \\
\text { (Lauraceae) }\end{array}$ & Australia & 112 & Paulus et al. (2003) \\
\hline $\begin{array}{l}\text { Castanopsis fissa } \\
\text { (Fagaceae) }\end{array}$ & Hong Kong & 38 & Tang et al. (2005) \\
\hline $\begin{array}{l}\text { Swida controversa } \\
\text { (Cornaceae) }\end{array}$ & Japan & 15 & Osono (2005) \\
\hline $\begin{array}{l}\text { Ficus pleurocarpa } \\
\text { (Moraceae) }\end{array}$ & Australia & 104 & Paulus et al. (2006) \\
\hline $\begin{array}{l}\text { Castanopsis diversifolia } \\
\text { (Fagaceae) }\end{array}$ & Thailand & 112 & Duong et al. (2008) \\
\hline $\begin{array}{l}\text { Shorea obtusa } \\
\text { (Dipterocarpaceae) }\end{array}$ & Thailand & 80 & Osono et al. (2009) \\
\hline $\begin{array}{l}\text { Quercus myrsinaefolia } \\
\text { (Fagaceae) }\end{array}$ & Japan & 83 & Shirouzu et al. (2009) \\
\hline $\begin{array}{l}\text { Anacardium occidentale } \\
\text { (Anacardiaceae) }\end{array}$ & India & 142 & Shanthi \& Vittal (2010a) \\
\hline $\begin{array}{l}\text { Pavetta indica } \\
\text { (Rubiaceae) }\end{array}$ & India & 54 & Promputtha et al. (2017) \\
\hline $\begin{array}{l}\text { Hevea brasiliensis } \\
\text { (Euphorbiaceae) }\end{array}$ & Thailand & 447 & Thailand \\
\hline $\begin{array}{l}\text { Magnolia liliifera } \\
\text { (Magnoliaceae) }\end{array}$ & 23 & Sittal (2010b) \\
\hline
\end{tabular}

Many previous experiments have focused on identifying fungal species and documenting leaf litter fungal diversity in single host species in various countries and climatic conditions (e.g. Anacardium occidentale, Camellia japonica, Castanopsis diversifolia, Ficus pleurocarpa, Manglietia garrettii, Magnolia liliifera, Quercus myrsinaefolia) (Promputtha et al. 2002, 2017, Paulus et al. 2003, 2006, Tang et al. 2005, Duong et al. 2008, Shanthi \& Vittal 2010a, b, Seephueak et al. 2010). Our knowledge on host specificity and host association of many fungi on leaf litter is still vague. Therefore, well-replicated, multi- host based experiments are needed to clarify these host related aspects connected to fungal colonization during the decomposition process.

Frequently, researchers do not consider interspecific competition and interactions of the species in succession process (Shearer 1995, Widden 1997, Jones \& Hyde 2002). This is a considerable oversight given that these interactions determine whether specific fungi are successful in colonization and how long they retain that territory (Boddy \& Hiscox 2017). Typically, first colonizers may have some specific adaptations for colonization on leaf litter and communities appearing later in the succession can be more adapted for invasion of existing communities (McNaughton \& Wolf 1973). Individual fungal species are capable of producing many different enzymes, which are suitable for physical and chemical decomposition of substrates (Promputtha et al. 2010, Boddy \& Hiscox 2017). Similarly, some fungal communities contribute to release of compounds that can affect growth and development of other fungal species (Shearer 1995). Nonetheless, only very few studies have focused on the above-mentioned aspects and thus, future studies should explore these topics further. 
Finally, there are only very few well-documented studies that have examined functional relationships between fungal succession and changes in chemical composition in leaf litter (Osono \& Takeda 1999, Koide et al. 2005, Osono 2005, Osono et al. 2009). Loss of soluble components generally occurs in the first stage, holocellulose decomposition in the second stage, lignin becomes a dominant component at the third stage and finally litter approaches humus (Osono 2005, Osono et al. 2009). Future studies need to focus on following the chemical composition in leaf litter and examine the role of fungal succession in litter decomposition processes in detail.

\section{Conclusions}

In the current context of climate change, studies on fungal communities on leaf litter are especially relevant. Leaf litter decomposition contributes to global carbon cycle and is an instrumental factor in ecological productivity, nutrient cycling and soil fertility. Fungal communities play significant roles in decomposition of leaf litter and have the ability to produce a wide range of extracellular enzymes. The fungal communities of various host species tend to change both quantitatively and qualitatively (fungal succession) during the decomposition process. This review focused on experimental methods, succession stages, controlling factors, limitations and future perspectives of leaf litter fungal succession studies. In particular, future research should focus on addressing the drawbacks of current succession studies. Most traditional methods have focused on collecting fruiting structures, isolating them in cultures and subsequently identifying them based on morphological characteristics. However, incapability to cultivate or identify all members of fungal communities by using morphology is a limiting factor in characterizing the entirety of the fungal diversity from their natural habitats, which is estimated to be large number, approximately 2.2-3.8 million species. Recent advances in technology, economic accessibility of molecular approaches such as next-generation sequencing, have contributed tremendously in identification of unknown diversity in leaf litter. Therefore upcoming fungal succession studies should essentially be geared towards molecular approaches as they can directly detect higher fungal diversity in leaf litter. NGS approaches despite being useful, have some limitations in identifying the majority of unknown taxa into species level and, obtaining correct names. In order to obtain better insights into species diversity of leaf litter, a combination of both approaches (i.e. traditional and culture-independent/molecular approaches) is needed in future succession studies.

\section{Acknowledgements}

The authors would like to thank Prof. Gareth Jones, Dr. T. K Goh, Dr. Derek Peršoh and Dr. Eric McKenzie for their comments, suggestions and help in correcting the manuscript. K.D. Hyde thanks Chiang Mai University for the award of Visiting Professorship. Thanks are also extended to Dr. Samantha Karunarathna, N.I de Silva, Anuruddha Karunarathna and Milan Samarakoon for their valuable suggestions and help. Dr. R. Jeewon thanks Mae Fah Luang University for the award of a Visiting Scholar and University of Mauritius for research support. The author would like to thank Mushroom Research Foundation (MRF), Chiang Rai Province, Thailand for providing research financial support and Postgraduate Scholarship.

\section{References}

Amarasinghe SL, Su S, Dong X, Zappia L et al. 2020 - Opportunities and challenges in long-read sequencing data analysis. Genome Biology 21, 1-16.

Ambardar S, Gupta R, Trakroo D, Lal R et al. 2016 - High throughput sequencing: an overview of sequencing chemistry. Indian Journal of Microbiology 56, 394-404.

Ananda K, Sridhar KR, Raviraja NS, Bärlocher F. 2008 - Breakdown of fresh and dried Rhizophora mucronata leaves in a mangrove of Southwest India. Wetlands Ecology and Management 16, 1-9.

Andrews JH, Hirano SS. 2012 - Microbial Ecology of Leaves. Springer Science \& Business Media. 
Austin AT, Vivanco L. 2006 - Plant litter decomposition in a semi-arid ecosystem controlled by photodegradation. Nature 442, 555-558.

Bani A, Pioli S, Ventura M, Panzacchi P et al. 2018 -The role of microbial community in the decomposition of leaf litter and deadwood. Applied Soil Ecology 126, 75-84.

Bärlocher F, Gessner MO, Garca MOS. 2020 - Methods to study litter decomposition. Springer International Publishing.

Berg B. 1991 - FDA-active fungal mycelium and lignin concentrations in some needle and leaf litter types. Scandinavian Journal of Forest Research 6, 451-462.

Berg B. 2000 - Litter decomposition and organic matter turnover in northern forest soils. Forest Ecology and Management 133, 13-22.

Berg B. 2014 - Foliar litter decomposition: a conceptual model with focus on pine (Pinus) litter-a genus with global distribution. ISRN Forestry 2014, 22.

Berg B, Laskowski R. 2006 - Litter decomposition: A guide to carbon and nutrient turnover. Academic Press, Amsterdam.

Berg B, McClaugherty C. 2003 - Plant Litter. Decomposition, Humus Formation, Carbon Sequestration. Springer-Verlag, Berlin Heidelberg New York.

Berg B, McClaugherty C. 2008 - Plant Litter Decomposition, Humus Formation, Carbon Sequestration. 2nd Ed, Berlin-Heidelberg: Springer.

Berg B, Berg MP, Bottner P, Box E et al. 1993 - Litter mass loss rates in pine forests of Europe and Eastern United States: Some relationships with climate and litter quality. Biogeochemistry 20, 127-159.

Bills GF, Polishook JD. 1994 - Abundance and diversity of microfungi in leaf litter of a lowland rain forest in Costa Rica. Mycologia 86, 187-198.

Blackwell M. 2011 - The fungi: 1, 2, 3 ... 5.1 million species? American Journal of Botany 98, 426-438

Boddy L, Hiscox J. 2017 - Fungal ecology: Principles and mechanisms of colonization and competition by saprotrophic fungi. The Fungal Kingdom 45, 293-308.

Boers SA, van der Reijden WA, Jansen R. 2012 - Highthroughput multilocus sequence typing: bringing molecular typing to the next level. PLoS One 7, 39630.

Bonanomi G, De Filippis F, Cesarano G, La Storia A et al. 2019 - Linking bacterial and eukaryotic microbiota to litter chemistry: Combining next generation sequencing with 13C CPMAS NMR spectroscopy. Soil Biology and Biochemistry 129, 110-121.

Booth C. 1971 - Methods in Microbiology, Vol. 4. London: Academic Press. 795.

Bothwell LD, Selmants PC, Giardina CP, Litton CM. 2014 - Leaf litter decomposition rates increase with rising mean annual temperature in Hawaiian tropical montane wet forests. PeerJ 2, e685.

Bray JR, Gorham E. 1964 - Litter production in forests of the world. Advances in Ecological Research 2, 101-157.

Bruns TD, White TJ, Taylor JW. 1991 - Fungal molecular systematics. Annual Review of Ecology and Systematics 22, 525-564.

Bucher VVC, Hyde KD, Pointing SB, Reddy CA. 2004 - Production of wood decay enzymes, mass loss and lignin solubilization in wood by marine ascomycetes and their anamorphs. Fungal Diversity 15, 1-14.

Burghouts T, Ernsting G, Korthals G, De Vries T. 1992 - Litter fall, leaf litter decomposition and litter invertebrates in primary and selectively logged dipterocarp forest in Sabah, Malaysia. Philosophical Transactions: Biological Sciences 335, 407-416.

Cannon PF. 1997 - Strategies for rapid assessment of fungal diversity. Biodiversity Conservation 6, 669-680.

Chauvet E, Giani N, Gessner MO. 1993 - Breakdown and invertebrate colonization of leaf Litter in two contrasting streams, significance of oligochaetes in a large river. Canadian Journal of Fisheries and Aquatic Sciences 50, 488-495. 
Chauvet E, Cornut J, Sridhar KR, Sélosse MA et al. 2016 - Beyond the water column: Aquatic Hyphomycetes outside their preferred habitats. Fungal Ecology 19, 112-127.

Chakravarty S, Rai P, Pala NA, Shukla G. 2020 - Litter Production and Decomposition in Tropical Forest. In: Gupta NC, Kuma A, Soares de Araújo F, Chandra KK, Singh AK, Srivastava N, editors. Handbook of Research on the Conservation and Restoration of Tropical Dry Forests. pp. 193-212. IGI Global.

Cooke RC, Rayner ADM. 1984 - Ecology of Saprotrophic Fungi. Longman, London.

Cotrufo MF, Briones MJI, Ineson P. 1998 - Elevated $\mathrm{CO}_{2}$ affects field decomposition rate and palatability of tree leaf litter: importance of changes in substrate quality. Soil Biology Biochemestry 30, 1565-1571.

Dechaine J, Ruan H, Sanchez de Leon Y, Zou X. 2005 - Correlation between earthworms and plant litter decomposition in a tropical wet forest of Puerto Rico. Pedobiologia 49, 601-607.

De Silva NI, Lumyong S, Hyde KD, Bulgakov T et al. 2016 - Mycosphere essays 9: defining biotrophs and hemibiotrophs. Mycosphere 7, 545-559.

De Silva NI, Phillips AJ, Liu JK, Lumyong S et al. 2019 - Phylogeny and morphology of Lasiodiplodia species associated with Magnolia forest plants. Scientific Reports 9, 1-11.

Devis AS, Yadava PS. 2007 - Wood and leaf litter decomposition of Dipterocarpus tuberculatus Roxb. in a tropical deciduous forest of Manipur, North East India. Current Science 93, 243 246.

Dilly O, Munch JC. 2001 - Shifts in physiological capabilities of the microbiota during the decomposition of leaf litter in black alder (Alnus glutinosa (Gaertn.) L.) forest. Soil Biology Biochemistry 33, 921-930.

Dilly O, Bloem J, Vos A, Munch JC. 2004 - Bacterial diversity in agricultural soils during litter decomposition. Applied and Environmental Microbiology 70, 468-474.

Dissanayake AJ, Purahong W, Wubet T, Hyde KD et al. 2018 - Direct comparison of culturedependent and culture-independent molecular approaches reveal the diversity of fungal endophytic communities in stems of grapevine (Vitis vinifera). Fungal diversity 90, 85-107.

Dix NJ, Webster J. 1995 - Fungal Ecology. Chapman \& Hall, London.

Donald J, Weir I, Bonnett S, Maxfield P et al. 2018 - The relative importance of invertebrate and microbial decomposition in a rainforest restoration project. Restoration Ecology 26, 220-226.

Dossa GG, Yang YQ, Hu W, Paudel E et al. 2021 - Fungal succession in decomposing woody debris across a tropical forest disturbance gradient: A field experiment. Soil Biology and Biochemistry 155, 108142.

Duong LM, McKenzie EHC, Lumyong S, Hyde KD. 2008 - Fungal succession on senescent leaves of Castanopsis diversifolia in Doi Suthep-Pui National Park, Thailand. Fungal Diversity 30, 23-36.

Eaton RJ, Barbercheck M, Buford M, Smitha W. 2004 - Effects of organic matter removal, soil compaction, and vegetation control on collembolan populations. Pedobiologia 48, 121-128.

Ellis MB. 1971 - Dematiaceous Hyphomycetes. Commonwealth Mycological Institute. Kew, United Kingdom.

Facelli JM, Pickett ST. 1991 - Plant litter: its dynamics and effects on plant community structure. The Botanical Review 57, 1-32.

Fayyad RJ, Muslim SN, Ali ANM. 2020 - Application strategies for using fungi and algae as bioremediators: a review. Plant Archives 20, 788-792.

Fioretto A, Di Nardo C, Papa S, Fuggi A. 2005 - Lignin and cellulose degradation and nitrogen dynamics during decomposition of three leaf litter species in a Mediterranean ecosystem. Soil Biology and Biochemistry 37, 1083-1091.

Frankland JC. 1976 - Decomposition of bracken litter. Botanical Journal of the Linnean Society 73, 133-143.

Frankland JC. 1992 - Mechanisms in fungal succession. The Fungal Community: its organization and role in the ecosystem 2, 383-401. 
Frankland JC. 1998 - Fungal succession - unraveling the unpredictable. Mycological Research $102,1-15$.

Froufe LCM, Schwiderke DK, Castilhano AC, Cezar RM et al. 2020 - Nutrient cycling from leaf litter in multistrata successional agroforestry systems and natural regeneration at Brazilian Atlantic rainforest biome. Agroforestry Systems 94, 159-171.

Fryar SC. 2002 - Fungal succession or sequence of fruit bodies. Fungal Diversity 10, 5-10.

Garrett SD. 1963 - Soil Fungi and Soil Fertility. Pergamon Press Ltd, London.

Garrido-Cardenas JA, Garcia-Maroto F, Alvarez-Bermejo JA, Manzano-Agugliaro F. 2017 - DNA sequencing sensors: an overview. Sensors 17, p.588.

Ge J, Xie Z, Xu W, Zhao C. 2017 - Controls over leaf litter decomposition in a mixed evergreen and deciduous broad-leaved forest, Central China. Plant and Soil 412, 345-355.

Giweta M. 2020 - Role of litter production and its decomposition, and factors affecting the processes in a tropical forest ecosystem: a review. Journal of Ecology and Environment 44, $1-9$.

Glassman SI, Weihe C, Li J, Albright MB et al. 2018 - Decomposition responses to climate depends on microbial community composition. Proceedings of the National Academy of Sciences 115, 11994-11999.

Guendehou GS, Liski J, Tuomi M, Moudachirou M et al. 2014 -. Decomposition and changes in chemical composition of leaf litter of five dominant tree species in a West African tropical forest. Tropical Ecology 55, 207-220.

Gonzalez G, Seastedt TR. 2001 - Soil fauna and plant litter decomposition in tropical and subalpine forests. Ecology 82, 955-964.

Graça MA. 2001 - The role of invertebrates on leaf litter decomposition in streams-a review. International Review of Hydrobiology 86, 383-393.

Gupta VK, Kubicek CP, Berrin JG, Wilson DW et al. 2016 - Fungal enzymes for bio-products from sustainable and waste biomass. Trends in Biochemical Sciences 41, 633-645.

Hasegawa M, Takeda H. 1996 - Carbon and nutrient dynamics in decomposing pine needle litter in relation to fungal and faunal abundances. Pedobiologia 40,171-184.

Hasanuzzaman M, Hossain M. 2014 - Leaf litter decomposition and nutrient dynamics associated with common horticultural cropland agroforest tree species of Bangladesh. International Journal of Forestry Research, Article ID 805940.

Hättenschwiler S. 2005 - Effects of tree species diversity on litter quality and decomposition. In: Scherer-Lorenzen M, Körner C, Schulze E-D, Eds. Forest diversity and function: temperate and boreal systems. Ecological Studies 176, 149-164.

Hättenschwiler S, Tiunov AV, Scheu S. 2005 - Biodiversity and litter decomposition in terrestrial ecosystems. Annual Review of Ecology Evolution and Systematics 36, 191-218.

Hawksworth DL. 1991 - The fungal dimension of biodiversity: magnitude, significance, and conservation. Mycological Research 95, 641-655.

Hawksworth DL. 2001 - The magnitude of fungal diversity: the 1.5 million species estimate revisited. Mycological Research 105, 1422-1432.

Hawksworth DL, Lücking R. 2017 - Fungal diversity revisited: 2.2 to 3.8 million species. Microbiology Spectrum 5, 1-17.

Ho WH, Hyde KD. 2002 - Fungal succession on fronds of Phoenix hanceana in Hong Kong. Fungal Diversity 10, 185-211.

Ho WH, Yanna, Hyde KD, Hodgkiss IJ. 2002 - Seasonality and sequential occurrence of fungi on wood submerged in Tai Po Kau Forest Stream, Hong Kong. Fungal Diversity 10, 21-43.

Holden SR, Gutierrez A, Treseder KK. 2013 - Changes in soil fungal communities, extracellular enzyme activities, and litter decomposition across a fire chronosequence in Alaskan boreal forests. Ecosystems 16, 34-46.

Hongsanan S, Xie N, Liu JK, Dissanayake A et al. 2018 - Can we use environmental DNA as holotypes?. Fungal Diversity 92, 1-30. 
Hou PCL, Zou X, Huang CY, Chien HJ. 2005 - Plant litter decomposition influenced by soil animals and disturbance in a subtropical rainforest of Taiwan. Pedobiologia 49, 539-547.

Huang Y, Ma Y, Zhao K, Niklaus PA et al. 2017 - Positive effects of tree species diversity on litter fall quantity and quality along a secondary successional chronosequence in a subtropical forest. Journal of Plant Ecology 10, 28-35.

Hudson HJ. 1968 - The ecology of fungi on plant remains above the soil. New Phytologist 67, 837-874.

Hyde KD, Bussaban B, Paulus B, Crous PW et al. 2007 - Diversity of saprobic microfungi. Biodiversity and Conservation 16, 7-35.

Hyde KD, Jeewon R, Chen YJ, Bhunjun CS et al. 2020 - The numbers of fungi: is the descriptive curve flattening?. Fungal Diversity 103, 219-271.

Hyde KD, Jones EG, Leaño E, Pointing SB et al. 1998 - Role of fungi in marine ecosystems. Biodiversity \& Conservation 7, 1147-1161.

Hyde KD, Norphanphoun C, Chen J, Dissanayake AJ et al. 2018 - Thailand's amazing diversity: up to $96 \%$ of fungi in northern Thailand may be novel. Fungal Diversity 93, 215-239.

Hyde KD, Xu J, Rapior S, Jeewon R et al. 2019 - The amazing potential of fungi: 50 ways we can exploit fungi industrially. Fungal Diversity 97, 1-136.

Jankowiak R. 2005 - Fungi associated with Ips typographus on Picea abies in southern Poland and their succession into the phloem and sapwood of beetle-infested trees and logs. Forest Pathology 35, 37-55.

Jayawardena RS, Purahong W, Zhang W, Wubet T et al. 2018 - Biodiversity of fungi on Vitis vinifera $\mathrm{L}$. revealed by traditional and high-resolution culture-independent approaches. Fungal diversity 90, 1-84.

Jeewon R, Hyde KD. 2007 - Diversity and detection of Fungi from environmental samples: Traditional versus Molecular approaches. In (Eds A. Varma \& R, Oelmuller) Advanced Techniques in Soil Microbiology. Soil Biology Series. Springer-Verlag Press. Pp. 1-11.

Jeewon R, Wanasinghe DN, Rampadaruth S, Puchooa D et al. 2017 - Nomenclatural and identification pitfalls of endophytic mycota based on DNA sequence analyses of ribosomal and protein genes phylogenetic markers: A taxonomic dead end? Mycosphere 8, 1802-1817

Jeewon R, Yeung QS, Wannasinghe DN, Rampadarath S et al. 2018 - Hidden mycota of pine needles: Molecular signatures from PCR-DGGE and Ribosomal DNA phylogenetic characterization of novel phylotypes. Scientific reports 8, 1-12.

Jia B, Zhou G, Xu Z. 2016 - Forest litter fall and its composition: a new data set of observational data from China. Ecology 97, 1365-1365.

Johnson EA, Catley KM. 2002 - Life in the leaf litter. American Museum of Natural History, New York.

Johnston SR, Boddy L, Weightman AJ. 2016 - Bacteria in decomposing wood and their interactions with wood-decay fungi. FEMS Microbiol Ecology 92: fiw179.

Jones EBG. 1963 - Marine fungi 11. Ascomycetes and Deuteromycetes from submerged wood and drift Spartina. Transactions of the British Mycological Society 40, 135-144.

Jones EBG, Hyde KD. 2002 - Succession: where do we go from here?. Fungal Diversity 10, 1-4.

Kainulainen P, Holopainen JK. 2002 - Concentrations of secondary compounds in Scots pine needles at different stages of decomposition. Soil Biology Biochemistry 34, 37-42.

Kearns SG, Bärlocher F. 2008 - Leaf surface roughness influences colonization success of aquatic Hyphomycete conidia. Fungal Ecology 1, 13-18.

Kjoller A, Struwe S. 1982 - Microfungi in ecosystems: fungal occurrence and activity in litter and soil. Oikos, 289-422.

Kodsueb R, McKenzie EHC, Lumyong S, Hyde KD. 2008 - Diversity of saprobic fungi on Magnoliaceae. Fungal Diversity 30, 37-53.

Koide K, Osono T, Takeda H. 2005 - Fungal succession and decomposition of Camellia japonica leaf litter. Ecological Research 20, 599-609. 
Krauss G, Sridhar KR, Jung K, Wennrich R et al. 2003 - Aquatic hyphomycetes in polluted groundwater habitats of Central Germany. Microbial Ecology 45, 329-339.

Krishna MP, Mohan M. 2017 - Litter decomposition in forest ecosystems: a review. Energy, Ecology and Environment 2, 236-249.

Laurence MH, Summerell BA, Burgess LW, Liew EC. 2014 - Genealogical concordance phylogenetic species recognition in the Fusarium oxysporum species complex. Fungal Biology 118, 374-384.

Leppert KN, Niklaus PA, Scherer-Lorenzen M. 2017 - Does species richness of subtropical tree leaf litter affect decomposition, nutrient release, transfer and subsequent uptake by plants? Soil Biology and Biochemistry 115, 44-53.

Li S, Tong Y, Wang Z. 2017 - Species and genetic diversity affect leaf litter decomposition in subtropical broadleaved forest in southern China. Journal of Plant Ecology 10, 232-241.

Lin Y, He X, Ma T, Han G et al. 2015 - Priority colonization of Cinnamomum camphora litter by endophytes affects decomposition rate, fungal community and microbial activities under field conditions. Pedobiologia 58, 177-185.

Liu M, Tang Y, Zhao K, Liu Y et al. 2017 - Determination of the fungal community of pit mud in fermentation cellars for Chinese strong-flavor liquor, using DGGE and Illumina MiSeq sequencing. Food Research International 91, 80-87.

Liu Y, Chen X, Liu J, Liu T et al. 2019 - Temporal and spatial succession and dynamics of soil fungal communities in restored grassland on the Loess Plateau in China. Land Degradation \& Development 30, 1273-1287.

Lodge DJ, Cantrell S. 1995 - Fungal communities in wet tropical forests: Variation in time and space. Canadian Journal of Botany 73, 1391-1398.

Lowman MD. 1988 - Litter fall and leaf decay in three Australian rainforest formations. Journal of Ecology 76, 451-465.

Luczkovich JJ, Knowles DB. 2000 - Successional and restoration: how ecosystems respond to disturbance. http://drjoe.ecu.edu/ch09/ch09.htm

Lynd LR, Weimer PJ, Van Zyl WH, Pretorius IS. 2002 - Microbial cellulose utilization: fundamentals and biotechnology. Microbiology and Molecular Biology Reviews 66, 506577.

Maria GL, Sridhar KR. 2003 - Diversity of filamentous fungi on woody litter of five mangrove plant species from the southwest coast of India. Fungal Diversity 14, 109-126.

Maria GL, Sridhar KR, Bärlocher F. 2006 - Decomposition of dead twigs of Avicennia officinalis and Rhizophora mucronata in a mangrove in southwest India. Botanica Marina 49, 450-455.

May RM. 2000 - The dimensions of life on earth. In: Raven PH, Williams T (eds) Nature and human society: the quest for a sustainable world. National Academy Press, Washington, pp $30-45$.

McKenzie EHC, Hudson HJ. 1976 - Mycoflora of rust-infected and non-infected plant material during decay. Transactions of the British Mycological Society 66, 223-238.

McNaughton SJ, Wolf LL. 1973 - General Ecology. Holt, Rinehard and Winston, Inc., New York, $710 \mathrm{p}$.

Melillo JM, Aber JD, Muratore JF. 1982 - Nitrogen and lignin control of hardwood leaf litter decomposition dynamics. Ecology 63, 621-626.

Moorhead D, Lashermes G, Recous S, Bertrand I. 2014 - Interacting microbe and litter quality controls on litter decomposition: a modeling analysis. PLoS One 9, p.e108769.

Nagraj T. 1978 - Genera Coelomycetum. 16. Fibulocoela form-gen nov, A Coelomycete with basidiomycetous affinities. Canadian Journal of Botany 56, 1485-1491.

Nikolcheva LG, Cockshut AM, Bärlocher F. 2003 - Determining Diversity of Freshwater Fungi on Decaying Leaves: Comparison of Traditional and Molecular Approaches. Applied and Environmental Microbiology 69, 2548-2554.

Niks RE, Rubiales D. 2002 - Potentially durable resistance mechanisms in plants to specialized fungal pathogens. Euphytica 124, 201-216. 
O’Brien HE, Parrent JL, Jackson JA, Moncalvo JM et al. 2005 - Fungal community analysis by large-scale sequencing of environmental samples. Applied and Environmental Microbiology $71,5544-5550$.

Olson DM. 1994 - The distribution of leaf litter invertebrates along a Neotropical altitudinal gradient. Journal of Tropical Ecology 10, 129-150.

Osono T. 2005 - Colonization and succession of fungi during decomposition of Swida controversa leaf litter. Mycologia 97, 589-597.

Osono T. 2007 - Ecology of ligninolytic fungi associated with leaf litter decomposition. Ecological Research 22, 955-974.

Osono T. 2017 - Leaf litter decomposition of 12 tree species in a subtropical forest in Japan. Ecological Research 32, 413-422.

Osono T, Takeda H. 1999 - Decomposing ability of interior and surface fungal colonizers of beech leaves with reference to lignin decomposition. European Journal of Soil Biology 35, 51-56.

Osono T, Takeda H. 2001 - Organic chemical and nutrient dynamics in decomposing beech leaf litter in relation to fungal ingrowth and succession during 3-year decomposition processes in a cool temperate deciduous forest in Japan. Ecological Research 16, 649-670.

Osono T, Ishii Y, Takeda H, Seramethakun T et al. 2009 - Fungal succession and lignin decomposition on Shorea obtusa leaves in a tropical seasonal forest in northern Thailand. Fungal Diversity 36, 101-119.

Ottosson E. 2013 - Succession of Wood-inhabiting Fungal Communities. Ph.D. Thesis, University of Uppsula, Department of Forest Mycology, Plant Pathology.

Parungao MM, Fryar SC, Hyde KD. 2002 - Diversity of fungi on rainforest litter in North Queensland, Australia. Biodiversity \& Conservation 11, 1185-1194.

Paulus B, Gadek P, Hyde KD. 2003 - Estimation of microfungal diversity in tropical rainforest leaf litter using particle filtration: the effects of leaf storage and surface treatment. Mycological Research 107, 748-756.

Paulus B, Gadek P, Hyde K. 2006 - Successional patterns of microfungi in fallen leaves of Ficus pleurocarpa (Moraceae) in an Australian tropical rain forest. Biotropica 38, 42-51.

Pavlović P, Kostić O, Jarić S, Gajić G et al. 2020 - The effects of leaf litter chemistry and anatomical traits on the litter decomposition rate of Quercus frainetto Ten. and Quercus cerris L. in situ. Archives of Biological Sciences 72, 543-553.

Pei Z, Leppert KN, Eichenberg D, Bruelheide H et al. 2017- Leaf litter diversity alters microbial activity, microbial abundances, and nutrient cycling in a subtropical forest ecosystem. Biogeochemistry 134, 163-181.

Perez-Harguindeguy N, Diaz S, Cornelissen JHC, Venramini F et al. 2000 - Chemistry and toughness predict leaf litter decomposition rates over a wide spectrum of functional types and taxa in central Argentina. Plant Soil 218, 21-30.

Peršoh D. 2015 - Plant-associated fungal communities in the light of meta'omics. Fungal Diversity $75,1-25$.

Photita W, Lumyong S, Lumyong P, Ho WH et al. 2001 - Fungi on Musa acuminata in Hong Kong. Fungal diversity 6, 99-106

Pirozynski KA, Shoemaker RA. 1971 - Some Coelomycetes with appendaged conidia. Canadian Journal of Botany 49, 529-541.

Polishook JD, Bills GF, Lodge DJ. 1996 - Microfungi from decaying leaves of two rain forest trees in Puerto Rico. Journal of Industrial Microbiology \& Biotechnology 17, $284-294$.

Ponge JF. 1991 - Succession of fungi and fauna during decomposition of needles in a small area of Scots pine litter. Plant and Soil 138, 99-113.

Prasannarai K, Ananda K, Sridhar KR. 1999 - Intertidal fungi in Mangalore Harbour, Southern India. Botanica Marina 42, 117-122.

Prescott CE. 2002 -. The influence of the forest canopy on nutrient cycling. Tree Physiology 22, 1193-1200. 
Prescott CE, Maynard DG, Laiho R. 2000 - Humus in northern: friend or foe? Forest Ecology and Management 133, 23-26.

Promputtha I, Hyde KD, McKenzie EH, Peberdy JF et al. 2010 - Can leaf degrading enzymes provide evidence that endophytic fungi becoming saprobes?. Fungal Diversity 41, 89-99.

Promputtha I, Lumyong S, Lumyong P, McKenzie EC et al. 2002 - Fungal succession on senescent leaves of Manglietia garrettii in Doi Suthep-Pui National Park, northern Thailand. Fungal Diversity 10, 89-100.

Promputtha I, Lumyong S, Dhanasekaran V, McKenzie EHC et al. 2007 - A phylogenetic evaluation of whether endophytes become saprotrophs at host senescence. Microbial Ecology 53, 579-590.

Promputtha I, McKenzie EH, Tennakoon DS, Lumyong S et al. 2017 - Succession and natural occurrence of saprobic fungi on leaves of Magnolia liliifera in a tropical forest. Cryptogamie Mycologie 38, 213-225.

Prosser JI, Bohannan BJM, Curtis TP, Ellis RJ et al. 2007 - The role of ecological theory in microbial ecology. Nature Reviews. Microbiology 5, 384-392.

Purahong W, Wubet T, Lentendu G, Schloter M et al. 2016 - Life in leaf litter: novel insights into community dynamics of bacteria and fungi during litter decomposition. Molecular Ecology 25, 4059-4074.

Purahong W, Kapturska D, Pecyna MJ, Schulz E et al. 2014 -Influence of different forest system management practices on leaf litter decomposition rates, nutrient dynamics and the activity of ligninolytic enzymes: A case study from Central European forests. PLoS One 9, e93700.

Purahong W, Wubet T, Kruger D, Buscot F. 2018 - Molecular evidence strongly supports deadwood-inhabiting fungi exhibiting unexpected tree species preferences in temperate forests. ISME Journal 12: article 289.

Purahong W, Mapook A, Wu Y, Chen C. 2019 - Characterization of the Castanopsis carlesii deadwood mycobiome by pacbio sequencing of the full-length fungal nuclear ribosomal Internal Transcribed Spacer (ITS). Frontiers in Microbiology 10, 983.

Rahman MM, Tsukamoto J, Tokumoto Y, Shuvo MAR. 2013 - The role of quantitative traits of leaf litter on decomposition and nutrient cycling of the forest ecosystems. Journal of Forest Science 29, 38-48.

Raviraja NS, Sridhar KR, Bärlocher F. 1996 - Breakdown of introduced and native leaves in two Indian streams. Internationale Revue der Gesamten Hydrobiologie und Hydrographie 81, 529-539.

Raviraja NS, Sridhar KR, Bärlocher F. 1998a - Fungal species richness in Western Ghat streams (Southern India): is it related to $\mathrm{pH}$, temperature or altitude? Fungal Diversity 1, 179-191.

Raviraja NS, Sridhar KR, Bärlocher F. 1998b - Breakdown of Ficus and Eucalyptus leaves in an organically polluted river in India: fungal diversity and ecological functions. Freshwater Biology 39, 537-545.

Rayner AD, Todd NK. 1979 - Population and community structure and dynamics of fungi in decaying wood. Advances in Botanical Research 7, 333-420.

Ristok C, Leppert KN, Franke K, Scherer-Lorenzen M et al. 2017 -. Leaf litter diversity positively affects the decomposition of plant polyphenols. Plant and Soil 419, 305-317.

Ritter CD, Dunthorn M, Anslan S, de Lima VX et al. 2020 - Advancing biodiversity assessments with environmental DNA: Long-read technologies help reveal the drivers of Amazonian fungal diversity. Ecology and Evolution 10, 7509-7524.

Robertson GP, Paul EA. 1999 - Decomposition and soil organic matter dynamics. In: Sala OE, Jackson RB, Mooney HA, Howarth RW (eds) Methods of ecosystem science. Springer, New York, pp 104-116.

Romaní AM, Fischer H, Mille-Lindblom C, Tranvik LJ. 2006 - Interactions of bacteria and fungi on decomposing litter: differential extracellular enzyme activities. Ecology 87, 2559-2569. 
Rossman AY. 1994 - A strategy for an all-taxa inventory of fungal diversity. In: Peng CI, Chou CH (eds) Biodiversity and terrestrial ecosystems. Academia Sinica Monograph Series No. 14. Taipei, pp 169-194

Saitta A, Anslan S, Bahram M, Brocca L et al. 2018 - Tree species identity and diversity drive fungal richness and community composition along an elevational gradient in a Mediterranean ecosystem. Mycorrhiza 28, 39-47.

Sayer EJ. 2006 - Using experimental manipulation to assess the roles of leaf litter in the functioning of forest ecosystems. Biological Reviews 81, 1-31.

Sayer EJ, Rodtassana C, Sheldrake M, Bréchet LM et al. 2020 - Revisiting nutrient cycling by litter fall - Insights from 15 years of litter manipulation in old-growth lowland tropical forest. Advances in Ecological Research 62, 173-223.

Schmidt PA, Bálint M, Greshake B, Bandow C et al. 2013 - Illumina metabarcoding of a soil fungal community. Soil Biology and Biochemistry 65, 128-132.

Schoch CL, Seifert KA, Huhndorf S, Robert V et al. 2012 - Nuclear ribosomal internal transcribed spacer (ITS) region as a universal DNA barcode marker for fungi. Proceedings of the National Academy of Sciences 109, 6241-6246.

Seephueak P, Petcharat V, Phongpaichit S. 2010 - Fungi associated with leaf litter of para rubber (Hevea brasiliensis). Mycology 1, 213-227.

Senanayake IC, Rathnayaka AR, Marasinghe DS, Calabon MS et al. 2020 - Morphological approaches in studying fungi: collection, examination, isolation, sporulation and preservation. Mycosphere 11, 2678-2754.

Shanthi S, Vittal BPR. 2010a - Biodiversity of microfungi associated with litter of Pavetta indica. Mycosphere 1, 23-37

Shanthi S, Vittal BPR. 2010b - Fungi associated with decomposing leaf litter of Cashew (Anacardium occidentale). Mycology 1, 121-129

Shanthi S, Vittal BPR. 2012 - Fungal diversity and the pattern of fungal colonization of Anacardium occidentale leaf litter. Mycology 3, 132-146.

Shearer CA. 1995 - Fungal competition. Canadian Journal of Botany 73, 1259-1264.

Shendure J, Ji H. 2008 - Next-generation DNA sequencing. Nature Biotechnology 26, 1135-1145.

Shirouzu T, Hirose D, Fukasawa Y, Tokumasu S. 2009 - Fungal succession associated with the decay of leaves of an evergreen oak, Quercus myrsinaefolia. Fungal Diversity 34, 87-109.

Sinsabaugh RL, Carreiro MM, Alvarez S. 2002 - Enzyme and microbial dynamics of litter decomposition. In: Burns RG, Dick RP (Eds) Enzymes in the environment: activity, ecology, and applications. Marcel Dekker, Inc., New York, pp 249-265.

Sridhar KR. 2009 - Fungi in the tree canopy - An appraisal. In: Applied Mycology (Ed. Rai, M. and Bridge, P.). CAB International, UK, 73-91.

Sridhar KR. 2012 - Decomposition of materials in the sea. In: Marine Fungi and Fungal-like Organisms (Ed. Jones EBG and Pang KL). Walter de Gruyter GmbH \& Co. KG, Berlin/Boston 45, 475-500.

Sridhar KR, Bärlocher F. 2000 - Initial colonization, nutrient supply and fungal activity on leaves decaying in streams. Applied and Environmental Microbiology 66, 1114-1119.

Sridhar KR, Karamchand KS, Sumathi P. 2010 - Fungal colonization and breakdown of sedge (Cyperus malaccensis Lam.) in an Indian mangrove. Botanica Marina 53, 525-533.

Sutton BC. 1980 - The coelomycetes. Fungi Imperfecti with Pycnidia, Acervuli and Stromata. Commonwealth Mycological Institute.

Swift MJ, Heal OW, Anderson MM. 1979 - Decomposition in Terrestrial Ecosystems. Blackwell Scientific Publications, Oxford, UK.

Takahashi S, Tomita J, Nishioka K, Hisada T et al. 2014 - Development of a prokaryotic universal primer for simultaneous analysis of bacteria and archaea using next-generation sequencing. PLoS One 9, 105592.

Talbot JM, Treseder KK. 2012 - Interactions among lignin, cellulose, and nitrogen drive litter chemistry-decay relationships. Ecology 93, 345-354. 
Tang AM, Jeewon R, Hyde KD. 2005 - Succession of microfungal communities on decaying leaves of Castanopsis fissa. Canadian Journal of Microbiology 51, 967-974.

Tedersoo L, Anslan S, Bahram M, Kõljalg U et al. 2020 - Identifying the 'unidentified'fungi: a global-scale long-read third-generation sequencing approach. Fungal Diversity 103, 273-293.

Tedersoo L, Tooming-Klunderud A, Anslan S. 2018 - PacBio metabarcoding of fungi and other eukaryotes: errors, biases and perspectives. New Phytologist 217, 1370-1385.

Thongkantha S, Lumyong S, McKenzie EHC, Hyde KD. 2008 - Fungal saprobes and pathogens occurring on tissues of Dracaena lourieri and Pandanus spp. in Thailand. Fungal Diversity 30, 149-169.

Tian G, Brussaard L, Kang BT, Swift MJ. 1997 - Soil fauna-mediated decomposition of plant residues under constrained environmental and residue quality conditions. In: Cadisch, G., Giller, K.E. (Eds.), Driven by Nature: Plant Litter Quality and Decomposition. CAB International, London.

Tripathi OP, Pandey HN, Tripathi RS. 2009 - Litter production, decomposition and physicochemical properties of soil in 3 developed agroforestry systems of Meghalaya, Northeast India. African Journal Plant Science 3,160-187.

Trofymow JA, Moore TR, Titus B, Prescott C et al. 2002 - Rates of litter decomposition over 6 years in Canadian forests: influence of litter quality and climate. Canadian Journal of Forest Research 32, 789-804.

Tsui KM, Hyde KD, Hodgkiss IJ. 2000 - Biodiversity of fungi on submerged wood in Hong Kong streams. Aquatic Microbial Ecology 21, 289-298.

Vargas DN, Bertiller MB, Ares JO, Carrera AL et al. 2006 -. Soil C and N dynamics induced by leaf-litter decomposition of shrubs and perennial grasses of the Patagonian Monte. Soil Biology and Biochemistry 38, 2401-2410.

Vasconcelos HL, Laurance WF. 2005 - Influence of habitat, litter type, and soil invertebrates on leaf-litter decomposition in a fragmented Amazonian landscape. Oecologia 144, 456-462.

Veen C, Fry E, ten Hooven F, Kardol P et al. 2019b - The role of plant litter in driving plant-soil feedbacks. Frontiers in Environmental Science 7, 168.

Veen GF, Snoek BL, Bakx-Schotman T, Wardle DA et al. 2019a - Relationships between fungal community composition in decomposing leaf litter and home-field advantage effects. Functional Ecology 33, 1524-1535.

Vivelo S, Bhatnagar JM. 2019 - An evolutionary signal to fungal succession during plant litter decay. FEMS Microbiology Ecology 95, p.fiz145.

Voř́šková J, Baldrian P. 2013 - Fungal community on decomposing leaf litter undergoes rapid successional changes. The ISME Journal 7, 477-486.

Wang Q, Wang S, Huang Y. 2009 - Leaf litter decomposition in the pure and mixed plantations of Cunninghamia lanceolata and Michelia macclurei in subtropical China. Biology and Fertility of soils 45, 371-377.

White TM, Bruns T, Lee S, Taylor J. 1990 - Amplification and direct sequencing of fungal ribosomal RNA for phylo-genetics. In: Innis MA, Gelfand DH, Sninsky JJ, White TJ. (Eds.), PCR Protocols: a guide to methods andapplications. Academic Press, San Diego, CA, 315321.

Widden P. 1997 - Competition and the fungal community. The Mycota 4, 135-148.

Wu BW, Gao C, Chen L, Buscot F et al. 2018 - Host phylogeny is a major determinant of Fagaceae-associated ectomycorrhizal fungal community assembly at a regional scale. Frontiers in Microbiology 9, 2409.

Xiong S, Nilsson C. 1997 - Dynamics of leaf litter accumulation and its effects on riparian vegetation: a review. The Botanical Review 63, 240-264.

Yang X, Chen J. 2009 -. Plant litter quality influences the contribution of soil fauna to litter decomposition in humid tropical forests, southwestern China. Soil Biology and Biochemistry 41, 910-918. 
Yin R, Eisenhauer N, Auge H, Purahong W et al. 2019 - Additive effects of experimental climate change and land use on faunal contribution to litter decomposition. Soil Biology and Biochemistry 131, 141-148.

Zhang N, Li Y, Wubet T, Bruelheide $\mathrm{H}$ et al. 2018 - Tree species richness and fungi in freshly fallen leaf litter: unique patterns of fungal species composition and their implications for enzymatic decomposition. Soil Biology and Biochemistry 127, 120-126.

Zhao B, Xing P, Wu QL. 2020 - Interactions between bacteria and fungi in macrophyte leaf litter decomposition. Environmental Microbiology 23, 1130-1144.

Zhou D, Hyde KD. 2002 - Fungal succession on bamboo in Hong Kong. Fungal Diversity 10, 213 227.

Zhou J, Lang X, Du B, Zhang H et al. 2016 - Litter fall and nutrient return in moist evergreen broad-leaved primary forest and mixed subtropical secondary deciduous broad-leaved forest in China. European Journal of Forest Research 135, 77-86.

Zhu W, Wang J, Zhang Z, Ren F et al. 2016 - Changes in litter quality induced by nutrient addition alter litter decomposition in an alpine meadow on the Qinghai-Tibet Plateau. Scientific Reports 6, 1-10. 